\title{
COLLAPSE ABOVE THE WORLD'S LARGEST POTASH MINE (URAL, RUSSIA)
}

\author{
Vjacheslav ANDREJCHUK
}

\begin{abstract}
This paper reports the results of the study of a huge collapse that occurred in June 1986 within the area of the 3rd Berezniki potash mine (the Verkhnekamsky potash deposit, Ural). Processes that took place between the first appearance of a water inflow through the mine roof and the eventual collapse are reconstructed in detail. The origin and development of a cavity that induced the collapse are revealed. Two factors played a major role in the formation of the collapse: the presence of a tectonic fold/rupture zone with in both the salt sequence and the overburden (the zone of crush and enhanced permeability), and the ductile pillars mining system.
\end{abstract}

KEYWORDS: collapse sinkhole, potash mine, Ural region, Russia

\section{Introduction}

The collapse that occurred within the area of the 3rd Berezniki potash mine (BPM-3) in July 1986 is one of the largest collapses ever to have occurred on salt deposits. It is unprecedented in terms of the depth of occurrence of the initiating cavity $(>400 \mathrm{~m})$. The collapse occurred at a location where the depth and geological setting of mining were considered to provide the safest conditions of the whole deposit with respect to the potential collapse. This is the only collapse that occurred during the entire life of the mine. This collapse event and the preceding flooding of the world's largest potash mine forced a revision of the development strategy for the deposit, especially the mining technology and the scope and aims of the accompanying scientific studies.

The collapse has raised an array of problems, the most important being the revealing of the causes of the mine flooding and the mechanisms of collapse formation. The author studied these issues for several years, in cooperation with the Geological Service of the "Uralkaliy" Enterprise. The paper presents a brief summary of the research, and a reconstruction of the geological and hydrogeological events and processes that led to the catastrophic collapse.

\section{Geological structure of the collapse site}

The Verkhnekamsky potash salt deposit is part of the Solikamsky potash-bearing 
basin. The basin is located in the northern section of the fore-Ural, on the left side of the Kama River, between the Vishera (in the north) and Yayva (in the south) rivers (Fig.1). The area of the basin is $>6,500 \mathrm{~km}^{2}$ (Kopnin, 1995).

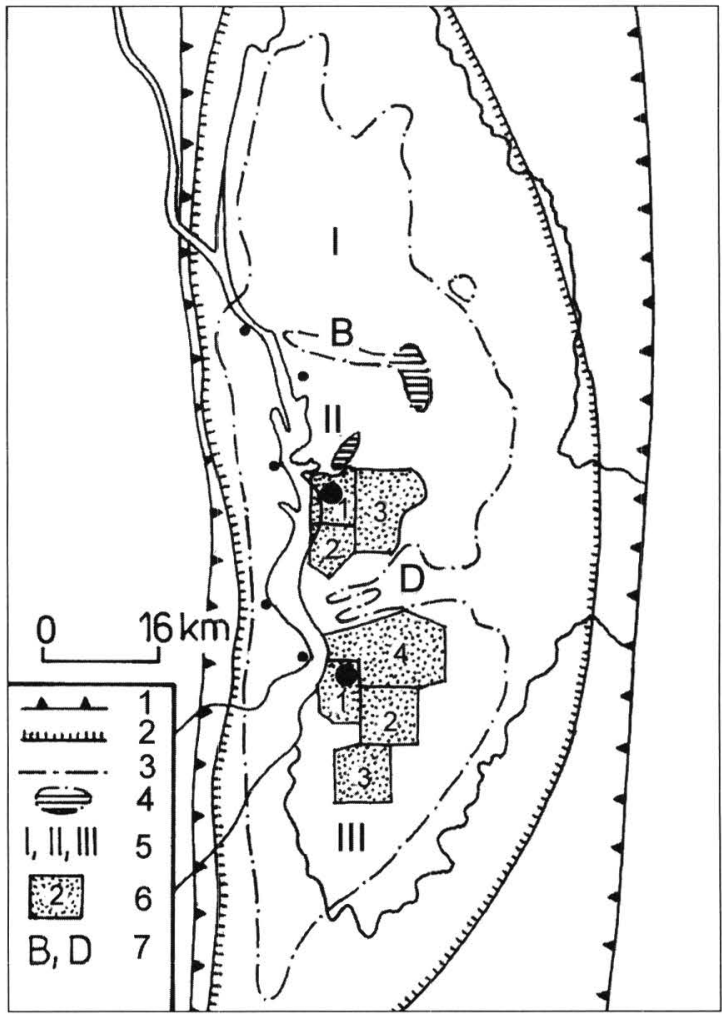

Fig.1 - Location of the Verkhnekamsky potash deposit.

Saliferous sediments occur in the Irensky horizon of the Kungursy Series and in the Solikamsky horizon of the Ufimsky Series of Permian age. The salt body represents a giant salt lens that stretches $200 \mathrm{~km}$ from north to south and is $50 \mathrm{~km}$ wide (Fig.2). The lens lies in the central part of the Solikamsky depression, the large $(250 \times 70 \mathrm{~km})$ structure within the fore-Ural deep. The salt deposit is complicated by dome-like dislocations resulting from halokinetic processes. The structures are asymmetrical, with their eastern flanks more gentle that the western, and their amplitude decreases eastwards from 150$300 \mathrm{~m}$ to $30-50 \mathrm{~m}$.

The maximum thickness of the salt deposit is $500 \mathrm{~m}$. In its upper part potassium and potassium-magnesium minerals occur, forming the worldrenowned Verkhnekamsky mineral salt deposit with enormous reserves of halite, potassium salts, potassium-magnesium salts and natural brines. The surveyed area of the spread of potassium salts is about $3,800 \mathrm{~km}^{2}$ (135 x 40-45km; Kopnin, 1995). Further prospecting is in progress on the deposit.

The total reserves of potassium-bearing minerals are estimated to comprise 56 billion tons of sylvinite (containing 9.8 billion tons of $\mathrm{K}_{2} \mathrm{O}$ ) and 76.5 billion tons of carnallite (Kopnin, 1996). The salts are mined by the room-and-pillar method. Two lithological zones are mined, each consisting of several productive beds: the lower 15 to $35 \mathrm{~m}$-thick sylvinite zone (beds $\mathrm{A}, \mathrm{Kr}-\mathrm{I}, \mathrm{Kr}-\mathrm{II}$ and $\mathrm{Kr}-\mathrm{III}$ ) and the upper sylvinite-carnallite zone containing nine potash beds (B, V, G, D, E, Zh, Z, I, and K) with eight intervening halite beds (B-V, G-D, and so on). The total thickness of the lower zone varies between 40 and $80 \mathrm{~m}$. Production is carried out by seven potash mines that belong to the "Uralkalij" and "Sylvinite" companies. The site where the catastrophic collapse occurred lies within the area of the $3^{\text {rd }}$ Bereznikovsky mine, within the southern part of the deposit (Fig.1B). 


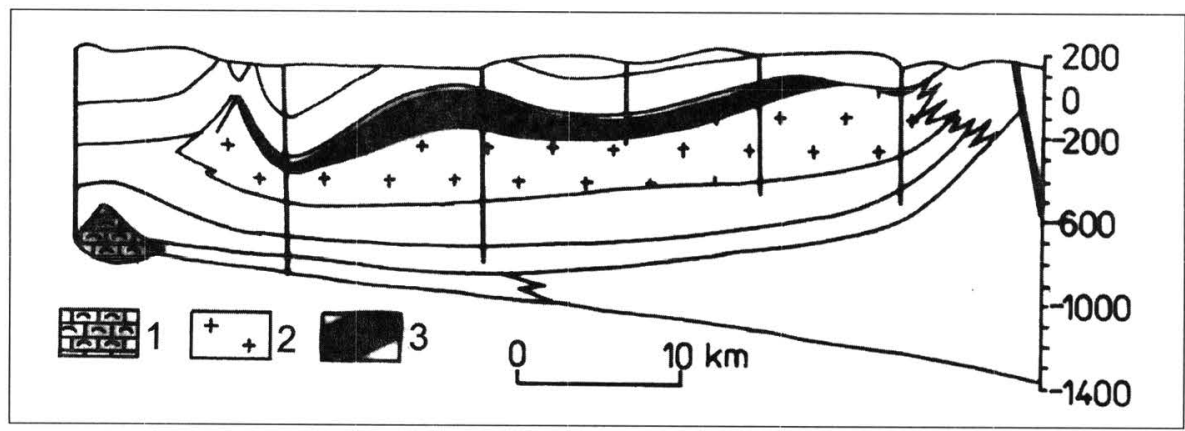

Fig.2 - Geological section across the Verkhnekamsky potash deposit (after Kopnin, 1995).

\subsection{Lithology and hydrogeology}

At the collapse site the underground mines lie at a depth of 235 to $425 \mathrm{~m}$ below the surface (Fig.3). Only the Kr-II bed of the sylvinite zone, with a thickness of 5 to $5.5 \mathrm{~m}$ was mined here. In this area the total thickness of the sylvinite-carnallite litho-zone is reduced, at the expense of replacement of carnallite by halite and sylvinite.

Above the productive horizon is the 100 to $110 \mathrm{~m}$-thick salt complex (intercalated halite and carnallite beds $)^{1}$. Its upper part $(25 \mathrm{~m})$, near its contact with overlying terrigenous sediments, is called the transitional zone, within which halite beds intercalate with marls and gypsum (anhydrite). The salt complex belongs to the Irensky Formation of the Kungursky Series $\left(\mathrm{P}_{1} \mathrm{~kg} \mathrm{ir}_{2}\right)$. Immediately above the uppermost salt bed of the transitional zone, two beds (each $2 \mathrm{~m}$ thick) of calcareous clays occur. Still higher (10 to $15 \mathrm{~m}$ above the uppermost salt bed), there are 3 brine aquifers, respectively 2, 3 and $5 \mathrm{~m}$ in thickness, with low specific yield. The brines are of Cl-Na composition (with minor amounts of $\mathrm{MgSO}_{4}$ and $\mathrm{MgCl}_{2}$ ), with a total dissolved solids content of about $300 \mathrm{~g} / \mathrm{dm}^{3}$.

Above the transitional zone lies the 50m-thick clay-marl sequence of the Solikamsky Formation $\left(\mathrm{P}_{2} \mathrm{sl}_{1}\right)$. Its upper part hosts an aquifer in fissured marls, which contains brines of $\mathrm{Cl}-\mathrm{Na}$ composition and TDS varying between 50-70 to $>300$ $\mathrm{g} / \mathrm{dm}^{3}$. The groundwaters have considerable head (up to $150 \mathrm{~m}$ or more). The lower part of the clay-marl sequence, which contains halite beds, together with the salt complex above the roof of the mines, comprise a lithological succession termed the waterproof complex (WPC). The waterproof characteristics of the succession are determined by its composition, which includes watertight salts, and by the presence of the brine aquifer, which protects the soluble salt rocks from the aggressive lowTDS waters of the overlying aquifers. Below the transitional complex the salt rocks do not contain brine horizons; such minor water shows as are observed are primary and related to sedimentation and diagenetic processes.

Above the clay-marl sequence, a 40m-thick limestone-marl sequence occurs, which is highly permeable and an aquifer, particularly in the culminations of brachyanticlinal structures. The aquifer is contained mainly in the upper part of the complex, where limestone predominates. Waters are $\mathrm{HCO}_{3}-\mathrm{Ca}$ in composition, and

\footnotetext{
${ }^{1}$ Names of divisions used in this paper are kept close to lithostratigraphic and mining nomenclature, and to terminology adopted by the local geological survey (Editors' note).
} 


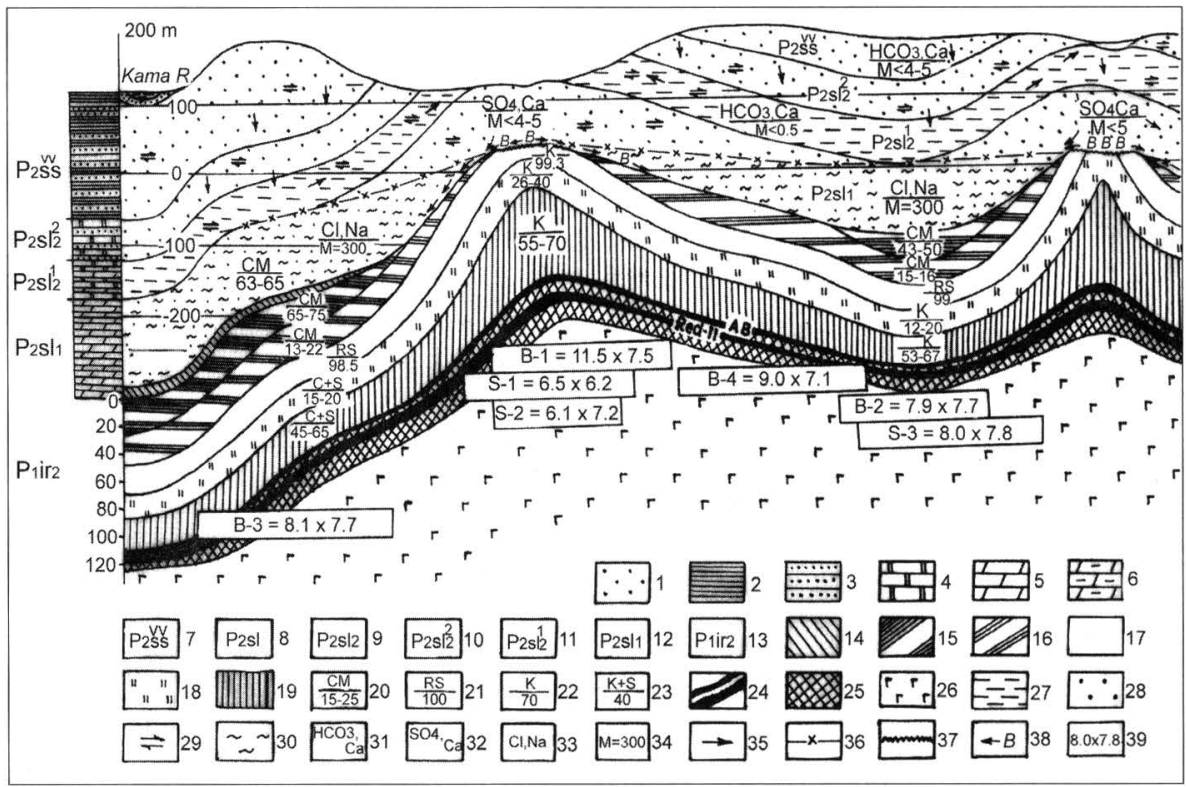

Fig.3 - Geological conditions of potash mining in the Verkhnekamsky deposit (after Kopnin, 1995): 1 = Quaternary sediments, $2=$ argillites, $3=$ aleurolites and sandstones, $4=$ dolomites, $5=$ marls, $6=$ clayey marls. Lithological divisions: $7=$ variegated complex (Sheshminskaya Series), $8=$ variegated complex (Solikamsky Series), $9=$ terrigenous-carbonate complex, $10=$ limestone-sandstone sequence, $11=$ limestone-marl sequence, $12=$ clay-marl sequence, $13=$ salt complex (Bereznikovskaja Series). The water-proof complex: 14 = transitional zone, the lower part of the clay-marl sequence with two halite beds, $15=$ salt-marl unit, $16=$ salt unit, $17=$ cover halite, 18 = halite-carnallite unit with potash beds $\mathrm{Zh}, \mathrm{Z}, \mathrm{I}$ and $\mathrm{K}, 19=$ carnallite unit with potash beds V, G, D and E. Component content in rocks, \%: $20=$ clays and marls, $21=$ halite, $22=$ carnallite, 23 = carnallite and sylvinite, $24=$ productive beds $A B$ and $K r-I I, 25=$ sylvinite litho-zone, 26 = halite. Groundwaters: 27 = relatively uniform, 28 = heterogeneous. Circulation zones: 29 $=$ active circulation, $30=$ sluggish circulation. Chemical types of groundwaters: $31=\mathrm{HCO} 3-\mathrm{Ca}$, $32=$ SO4-Ca, $33=\mathrm{Cl}-\mathrm{Na}, 34=\mathrm{TDS}, \mathrm{g} / \mathrm{dm} 3,35=$ directions of flow, $36=$ fresh water $/$ brine interface, 37 = salt karst level, $38=$ movement of karst brines, $39=$ dimensions of mining fields. Potash mines and their numbers: $B$-Bereznikovsky, $C$-Solikamsky.

the TDS is of the order of 0.2 to $0.5 \mathrm{~g} / \mathrm{dm}^{3}$. The aquifer is recharged by infiltration of meteoric precipitation (where the beds crop out at the surface), and also by crossformational flow from aquifers located above and below (in the areas of fold plunge). At the collapse site the aquifer was confined, containing water under pressure.

The limestone-marl sequence grades upwards into sandstones, limestones and aleurolites which constitute the limestone-sandstone sequence $\left(\mathrm{P}_{2} \mathrm{sl}_{2}{ }^{2}\right)$ of $50 \mathrm{~m}$ in thickness. It contains a prolific aquifer (well yield is $10 \mathrm{l} / \mathrm{s}$ or more) with water of low TDS $\left(0.2-0.5 \mathrm{~g} / \mathrm{dm}^{3}\right)$ and $\mathrm{HCO}_{3}-\mathrm{Ca}$ composition. Recharge is from meteoric precipitation and the adjacent aquifers. At the collapse site the aquifer receives recharge from the aquifer above.

The limestone-marl sequence and the limestone-sandstone sequences together comprise the terrigenous-carbonate complex (TCC), and the underlying transitional zone and clay-marl sequences together are distinguished as the salt-marl complex 
(SMC). The Permian succession is capped by the multi-coloured (variegated) complex (PCC), composed of argillites, aleurolites and sandstones with a total thickness of about $100 \mathrm{~m}\left(\mathrm{P}_{2} \mathrm{Ss}_{1}\right.$, the Sheshminskaya Series). Because of the lithological heterogeneity of the sequence, several small water-producing intervals located at various depths are relatively isolated, connected only adjacent to tectonic faults. The groundwaters are of $\mathrm{HCO}_{3}$-Ca composition and low in TDS $\left(0.2\right.$ to $\left.0.3 \mathrm{~g} / \mathrm{dm}^{3}\right)$. The aquifers are recharged from meteoric precipitation and they drain into erosional valleys and underlying horizons.

Quaternary deposits comprise a glacio-fluvial sandy-loam sequence about $20 \mathrm{~m}$ in thickness. It contains $\mathrm{HCO}_{3}$-Ca waters low in TDS (about $0.2 \mathrm{~g} / \mathrm{dm}^{3}$ ).

In a structural context, the collapse site lies in the lower part of the Durimansky synclinal structure. The mined section of the productive bed is located in the lowermost part of the tectonic depression and of the mining field (Fig.4).

On the basis of the thickness of the waterproof sequence (120 to $140 \mathrm{~m})$ the collapse site had been regarded as one of the safest areas, and favorable for mining. During 1984 and 1985 sylvinite had been using the room-and-pillar system with the following parameters. The width of the rooms was $5.3 \mathrm{~m}$, the height of rooms was $5.5 \mathrm{~m}$, and the width of pillars between the rooms was $3.8 \mathrm{~m}$. In due course the pillars crashed and the roofs sagged. This is why such a mining system is called the system of ductile pillars. It appears that this mining method played a substantial role in the failure of room ceilings and the flooding of the mine.

\subsection{Fissuring of rocks}

According to traditional views fissures do not develop in plastic salt sequences. Thus, such sequences are assumed to be water-tight and capable of providing a protective cover to mines. Micro-fissuring is commonly characteristic only of halopelitic beds, developing in the course of deformation of salt beds and halo-pelitic intercalations, due to their differing physical-mechanical properties.

Studies during the last 10 - to 15 years, especially those conducted in the Verkhnekamsky deposit, have led to a revision of traditional beliefs concerning fissuring in salts. Fissures were commonly observed by mine geologists during routine inspection of the productive sequences and in mine shafts. It was found that the "waterproof sequence" contains rupture deformations with zones of weakness developed along them. Various deformations develop as a result of both natural and anthropogenic factors (Andrejchuk, 1989). Rocks within the waterproof sequence also contain localized zones of fissuring, developed during halo-kinetic deformation of the beds (Filippov and Korochkina, 1990). Fissures and ruptures in the salts are commonly re-sealed (zones of replacement; Jarzhemsky and Tretjakov, 1989), but fresh ones (mining-related) can be open and penetrable by fluids.

Rupture deformations, especially anthropogenic fissures of displacement, foliation and unloading, present a considerable hazard as potential routes for brine rush into mines. In most cases anthropogenic ruptures develop inevitably along weakened zones, such as former deformations that have been sealed. Such zones are traced to considerable depths in the cover salt, evidencing past tectonic events (salt tectonics and also tectonic movements on a regional scale). They can contain brines in some sections. The threat of tectonically weakened zones is that they serve as tracks that link the cover salt sequence (above the mines), the brines in the overlying transitional zone and the lower parts of the clay-marl zone. 


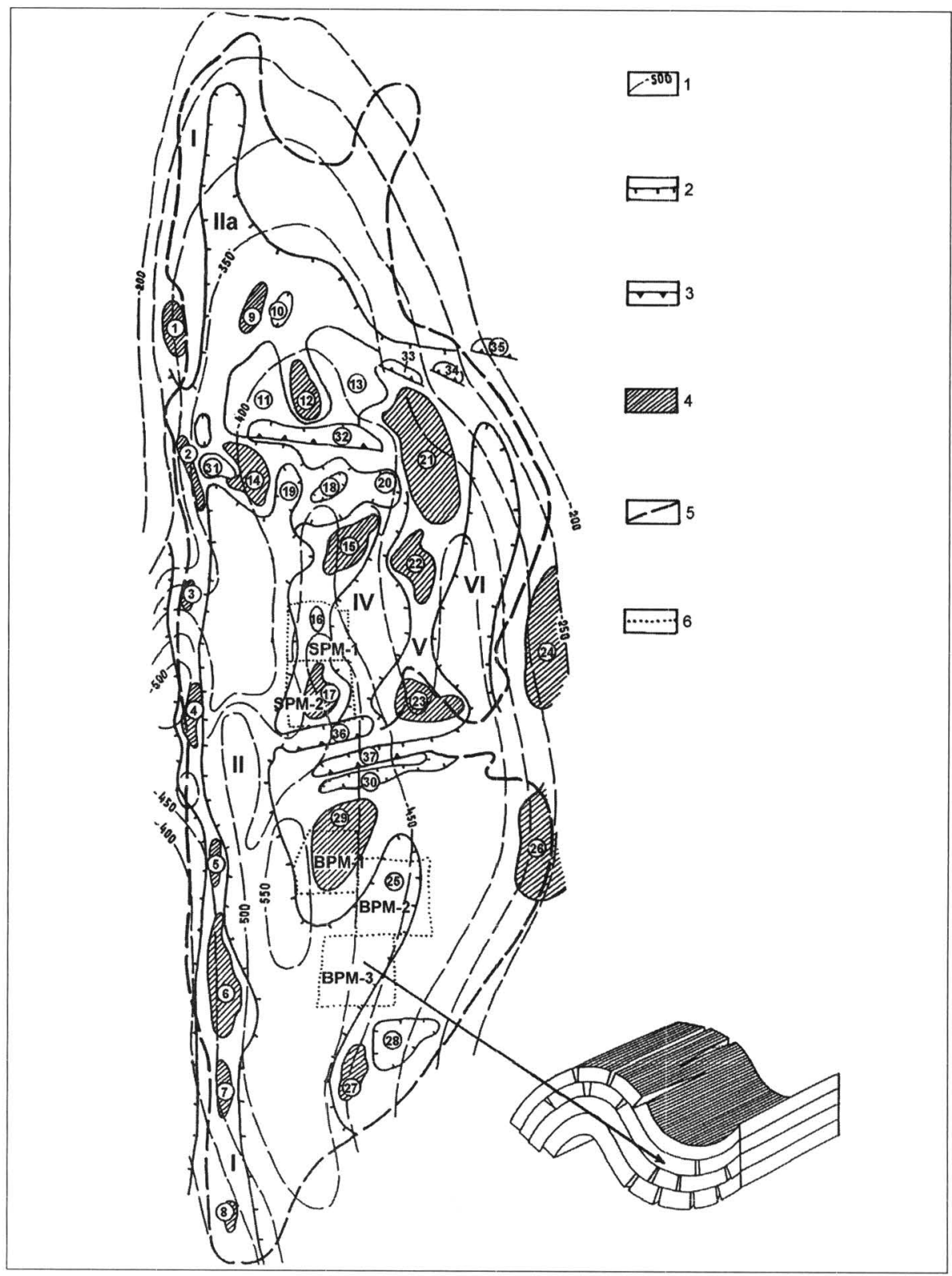

Fig.4 - Simplified structural map of the salt deposit (after materials of the geological survey of the Bereznikovsky mine No. 3). 1 = elevation contours of the bottom of the salt deposit, $2=$ contours of structures, 3 = flexures, $4=$ brachyanticline structures, $5=$ contours of the potash deposit, $6=$ contours of mining fields. Main structures: $I=$ Kamsko-Vishersky dome and its brachyanticline highs, $I I=$ Kamsky depression, III = Solikamsky anticline structure with brachyanticline highs, $I V=$ Tveritinsky depression, $V=$ Kharjushinskaja anticline structure with brachyanticline highs, VI = Osokinsky depression. Numbers in circles = main positive salt struc- 
A complementary danger rising "from below" (from the mines) is presented by the fresh anthropogenic fissures that form above the mine rooms due to the sagging of their roofs. Studies have demonstrated that in the case of room-and-pillar mining, plastic deformation of roofs in rooms leads first to foliation of stratified sediments, and then to the development of fissured zones above the rooms, extending upwards for some tens of metres. Displacement fissures that form above rooms penetrate even higher into the cover salt sequence.

Most likely the interception of a weakened zone in the cover salt by an anthropogenic fissure caused activation of the former and the opening of flow paths along it. These paths allowed brines from above to penetrate into the mines. The existence of such a weakened zone is suggested by several geological observations. The most important one is a fold deformation in the overburden, observed in the wall of the collapse. This fold is marked by a high level of fissuring and high permeability (Fig.5).

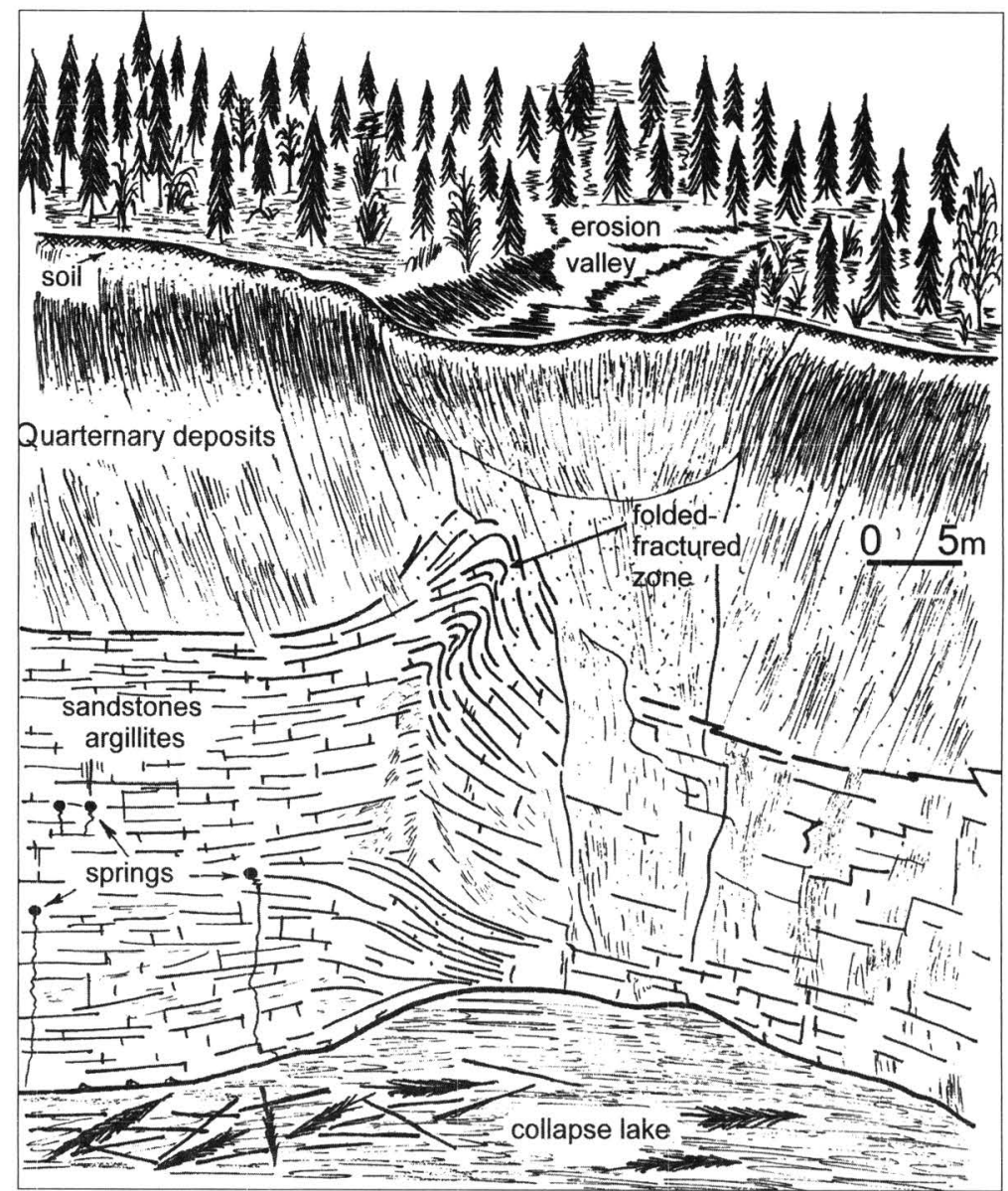

Fig.5 - Sketch of the northwestern side of the Berezniki Collapse (June, 1987). Arrows point to the fold deformation in the variegated complex 
According to the general model of folded structures, rupture deformations are distributed differently on the uplifted and lowered parts of a structure (Fig.4). The collapse is located on a syncline, where the culmination is characterised by low fissure frequency and by the presence of compressional microfolds. In the downward direction the density of ruptures increases, as does the width of the openings. It is reasonable to assume that the observed fold structure gives way downwards to a rupture structure, a vertical crush-zone, with enhanced fissuring and permeability, which penetrates into the upper part of the salt deposit. The presence of a large fault is also suggested by observations of piezometric levels and water circulation in the overburden.

It is apparent that this fold-rupture structure played a major role in the formation of the collapse. Firstly, the structure provided a path for inflow of fresh waters into the salt sequence and the mine. Secondly, the broken zone facilitated and guided failure of the roof of a cavity that formed in the salt, and supported its upward stoping. Because of the fragmentation of rocks in the fold zone the breakout dome could not reach equilibrium and a stable shape, so stoping continued. If the fold-rupture structure had not been there, a cavity at such a large depth would have formed a stable ceiling and survived for a significant length of time (from tens of years to a thousand years) without opening to the surface.

Below, a sequence of events that occurred in the collapse site is reconstructed, starting from the first appearance of water inflow into the room ceiling and continuing until formation of the collapse at the surface.

\section{Formation of a cavity in the salt sequence above the mine}

\subsection{Appearance of leakage in the mine roof}

The Bereznikovsky No.3 mine was one of the largest in the world. At the time of flooding the total volume of workings was estimated to be 15 million $\mathrm{m}^{3}$ (Kotel'nikov and Minkevich, 1990).

The fourth western working, where the collapse occurred, lies in the northwestern section of the mining field. During the night of January 11 1986, brine inflow was recorded in the roof of room No.50. At 12:00 on January 11 inflows also appeared in the roof of room No.52. Two days later, on January 13, inflows were also found in rooms 48 and 54, and then in some other rooms (Fig.6).

Brines that came from the mine roofs differed in composition from primary and condensation brines by having a diminished content of $\mathrm{Br}$ and $\mathrm{CaCl}_{2}$ and elevated content of $\mathrm{NaCl}$ and $\mathrm{CaSO}_{4}$. This indicated that they originated from the cover salt sequence, which is composed mainly of halite, containing gypsum and anhydrite interbeds in the upper part. Inflows occurred as streamlets entering under pressure.

Observations of the discharge and chemical composition of the inflows were started on January 11. They continued until March 8, and finished just before the disastrous situation that occurred due to increase of water inflow. On March 9 all people were evacuated from the mine, but all the mining equipment was left underground.

Observations made before March 8 allow tracking of the dynamics of water inflow and the solute load during a two-month period (Fig.7). A conjugate analysis of the hydrograph and chemograph allows characteristic periods to be distinguished and inferences to be drawn about processes that took place in the salt sequence above 


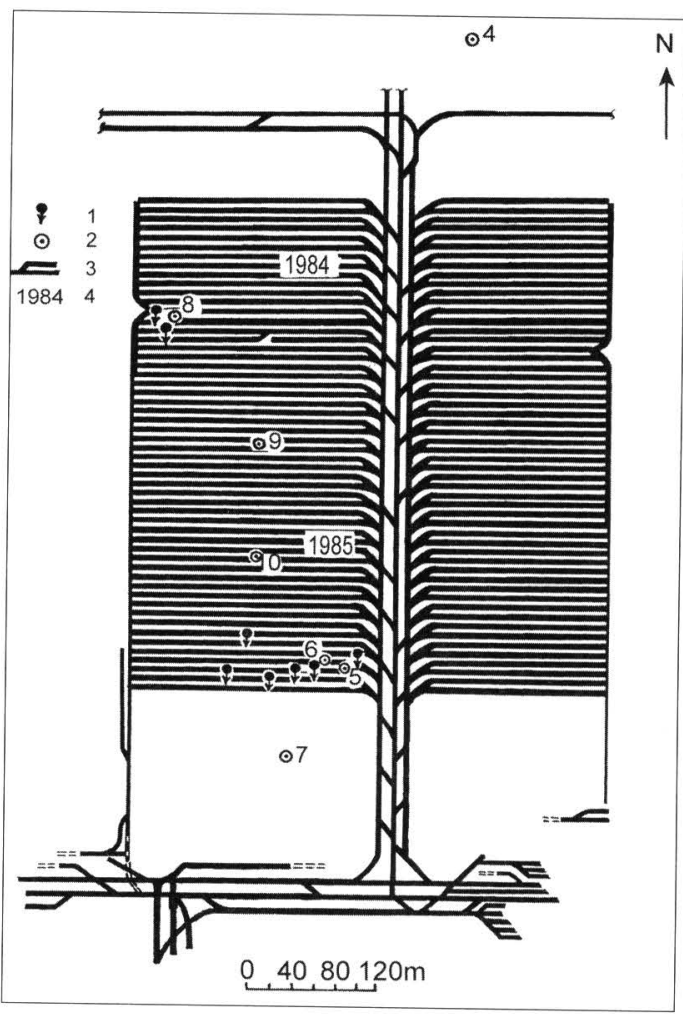

Fig.6 - Part of the mining field in which brine inflows in roofs of workings were recorded. the mine during these periods. Three main periods with characteristic data curves can be discriminated:

1) January 11 to January 15 : relatively steep growth of discharge (from 10 to $30 \mathrm{~m}^{3} / \mathrm{h}$ ), abrupt drop of TDS in brines (from 370 to $343 \mathrm{~g} / \mathrm{dm}^{3}$ ), rapid increase of the contents of $\mathrm{NaCl}$ (from 25 to $160 \mathrm{~g} / \mathrm{dm}^{3}$ ) and $\mathrm{SO}_{4}$ (from 0.5 to $1.6 \mathrm{~g} / \mathrm{dm}^{3}$ ) and decrease of $\mathrm{MgCl}_{2}$ (from 270 to $115 \mathrm{~g} / \mathrm{dm}^{3}$ ), $\mathrm{CaCl}_{2}$ (from 30 to $13 \mathrm{~g} / \mathrm{dm}^{3}$ ) and $\mathrm{Br}$ (from 4.2 to 0.9 $\left.\mathrm{g} / \mathrm{dm}^{3}\right)$.

2) January 16 to Ferbuary 2023: relatively slow growth of discharge (from 30 to $100 \mathrm{~m}^{3} / \mathrm{h}$ ), decrease of TDS (from 345 to $323 \mathrm{~g} / \mathrm{dm}^{3}$ ) and the content of $\mathrm{MgCl}_{2}$ (from 115 to $25 \mathrm{~g} / \mathrm{dm}^{3}$ ), $\mathrm{CaCl}_{2}$ (from 13 to $2 \mathrm{~g} / \mathrm{dm}^{3}$ ), $\mathrm{Br}$ (from 0,9 to $0,3 \mathrm{~g} / \mathrm{dm}^{3}$ ) and increase of the content of $\mathrm{NaCl}$ (from 160 to $270 \mathrm{~g} / \mathrm{dm}^{3}$ ) and $\mathrm{SO}_{4}$ (from 1,6 to $3,9 \mathrm{~g} / \mathrm{dm}^{3}$ ).

3) February 21-24 to March 8: abrupt growth of discharge (from 100 to $>350 \mathrm{~m}^{3} / \mathrm{h}$ ), fluctuating TDS and chemical composition.

It is apparent from the graphs that the first and third periods were relatively short (5 and 13-14 days), and the second period was more prolonged (35-37 days). During the first and second periods, despite their different duration, correlation of discharge, TDS and the chemical composition of the brines is well expressed.

After anthropogenic activation of flow paths in the cover salt brines rejuvenated within the "waterproof zone". Before that the brines were of a different nature. The lower part of the zone contained bittern brines, and the upper part contained brines formed due to dissolution of gypsum, anhydrite and halo-pelites. Various parts of the zone could contain primary brines related to diagenetic transformations of the rock (dissolution, re-crystallization and compaction). The anthropogenic opening of the zone provoked drainage of the different brines into the mine, accompanied by dissolution under pressure.

At a certain moment the zone became permeable across most or the whole of its thickness, and brines began moving down into the mine. At the beginning the bittern brines, the densest variety, were pressed out. This took place during the first period, evidenced by the prevalence of $\mathrm{MgCl}_{2}$ in the brine composition. This component also 


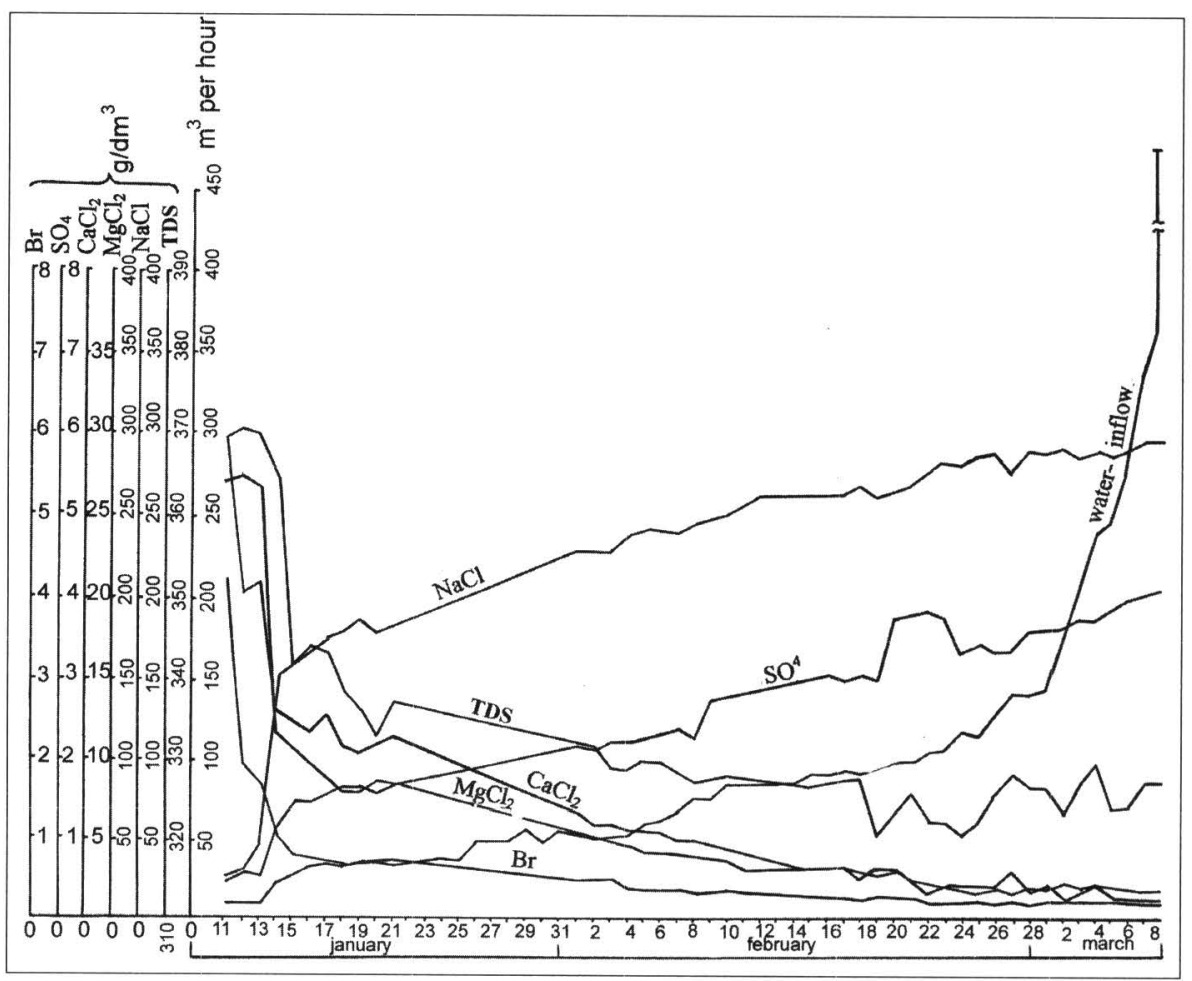

Fig. 7 - Dynamics of brine composition and discharge in the workings of block $N^{o} 8$ in JanuaryMarch 1986.

indicates that the brines came from the closest segment of the flow paths, i.e. from the potassium-magnesium section of the sequence, which includes the productive bed with mined tunnels.

After brines had been forced out of the nearest section, and after improvement of flow paths, movement of brines was activated in still higher (the middle and upper) parts of the zone. As the middle part is composed by halite, the second period demonstrates increase in $\mathrm{NaCl}$ content. Increase in $\mathrm{SO}_{4}$ content indicates the connection of flow paths with the upper section of the zone, which contains gypsum and other sulphate minerals. Decreasing TDS indicates progressive improvement (dissolutional growth) of flow paths connecting the upper part of the zone with the mine.

As a result of the more than one month-long outflow of salts from the cover salt beds and the transitional zone, flow paths above the mine were activated and enlarged enough to drain brines from the upper part of the waterproof zone effectively and to involve low-mineralized waters from the upper aquifers. This began in the third period, when discharge increased abruptly and TDS and chemical composition began fluctuating. A period when the curves oscillated against the background of the growing discharge reflects the "critical state" of the flow paths, after which nothing could prevent a catastrophic inrush of aggressive waters and the flooding of the mine. The catastrophic stage began during March 8-9. 


\subsection{Volume of cavities formed}

Before reconstructing further development of the processes that eventually led to the collapse, it is necessary to assess the transformations that occurred in the sequence during the monitored period. Beginning during the early days of the second period, brines that were formed due to dissolution of host rocks started arriving in the mines. The volume of primitive brines that had been pressed out of the waterproof zone was small. Dissolution was most intense in the upper part of the zone, where groundwater had a lower TDS content. Thus, a model of reversed "cone" can be taken as an approximation of the distribution of newly formed cavities.

Fig. 8 depicts the formation of cavities by dissolution of salts during the period between January 11 and March 8 1986, when regime observations on the water inflows to the mine were carried out. During the first period the volume of cavities formed was $336 \mathrm{~m}^{3}$. During the second period a volume of about $10,000 \mathrm{~m}^{3}$ was added. Approximately the same volume was added during the third period, when discharge of brines was growing abruptly. By March 9 cavities with a total volume of $20,500 \mathrm{~m}^{3}$ had formed. Most likely, a single cavity continued downwards as a system of bifurcating vertical conduits. However, the shape of the cavity formed by this stage had no significant influence on subsequent events, as later the cavity enlarged by two orders of magnitude.

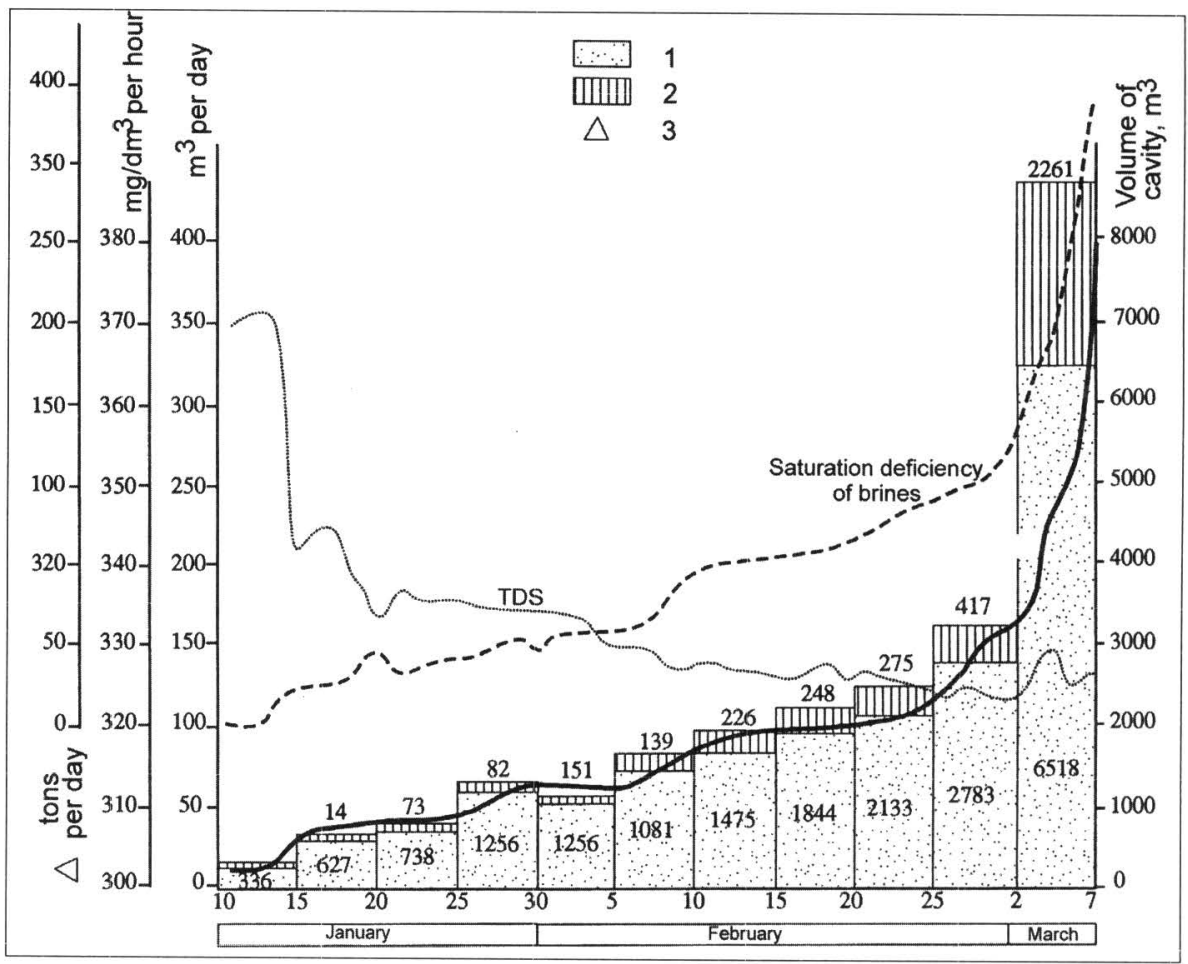

Fig.8 - Dynamics of salt dissolution and cavities formation in the damage zone of mine $\mathrm{N}^{o} 3$ between January 11 -March 81986.1 = the volume of cavities formed above the mine by inflowing undersaturated brines $(20,500 \mathrm{~m} 3)$, the volume of cavities formed at the mine level $(4,221 \mathrm{~m} 3)$, $3=$ saturation deficiency of brines arrived to the mine. 


\subsection{Flooding of the mine and the formation of a huge cavity in the cover salt}

From March 8-9 the water inflow into the mines became catastrophic, and a karstic cavity began to enlarge rapidly in the cover salt. All necessary conditions were present for fast dissolution: access of aggressive waters from the upper aquifers, the presence of well-developed conduits in the salt sequence and the large receptacle capacity of mine rooms (about 15 million $\mathrm{m}^{3}$ ), in which the brines accumulated. Because of drainage of brines from the top of the waterproof zone and the lower part of the clay-marl sequence, a drawdown cone was formed in the aquifers above the cover salt (Fig.10, the initial stage). Subsequent involvement of fresh waters from the overlying aquifers led to the formation of a general drawdown zone above the leakage area, traceable vertically for several hundred metres, including the aquifer of the (variegated) complex (Fig.9). It was possible to trace the development of the depression zone thanks to the several observation wells that already existed and those urgently drilled above the mine.

The tectonic structure described above provided a path of high vertical permeability. Starting at the beginning of March, it guided rapid development of a cavity, which grew upwards from below. This cavity drained laterally-extending aquifers that it intercepted. Hydrodynamic development along this path continued until the collapse occurred. Because of the free-fall flow conditions in the vertical cavity and the high flow velocities, the water removed tiny solid particles from fissures and caused decompaction and disintegration of rocks along the structure. Such weakening of the folded/disrupted zone favoured the subsequent gravitational breakdown of rocks.

The fresh waters coming into the salt sequence were highly aggressive. During the early stages the cavity probably had a reversed cone shape. It was widest at the level of the upper transitional zone, and narrowed downward. After establishment of freefall flow conditions, aggressive waters quickly perforated the inclined salt walls at the base, and the shape of the cavity was eventually transformed to cylindrical. The cavity had merged with the mine. After formation of a cylindrical cavity the zone of intense dissolution moved to its base, to the level of the mine. Pillars and remaining barriers between the cavity and mine rooms were quickly removed by dissolution. Fast development of the cavity is suggested by the fact that inflow of aggressive waters was measured in tens and, eventually, hundreds of $\mathrm{m}^{3}$ per day.

Fig.10 is helpful in providing some quantitative estimates and relating events to time. The figure is a record of the main events that occurred at the site between the first appearance of the water inflow in the mine and the eventual collapse. The situation discussed above corresponds to the period from the beginning of March until about April 20. This month-and-a-half period was the main stage in the formation of the cavity in the salts. The end of April presents an important milestone, when intense failure of the cave roof began (the formation of a breakout dome) and the flooding of the mine was completed. After about April 20 the whole mine (about 15 million $\mathrm{m}^{3}$ ) was inundated. This is evidenced by the behaviour of the piezometric level in the mine shafts.

For the most part the mine brines were supersaturated, and only near the damage area did undersaturated brines continue to dissolve the room walls. Knowing the volume of the mine and time of the inundation (March 8-9 to April 15-20), one can 


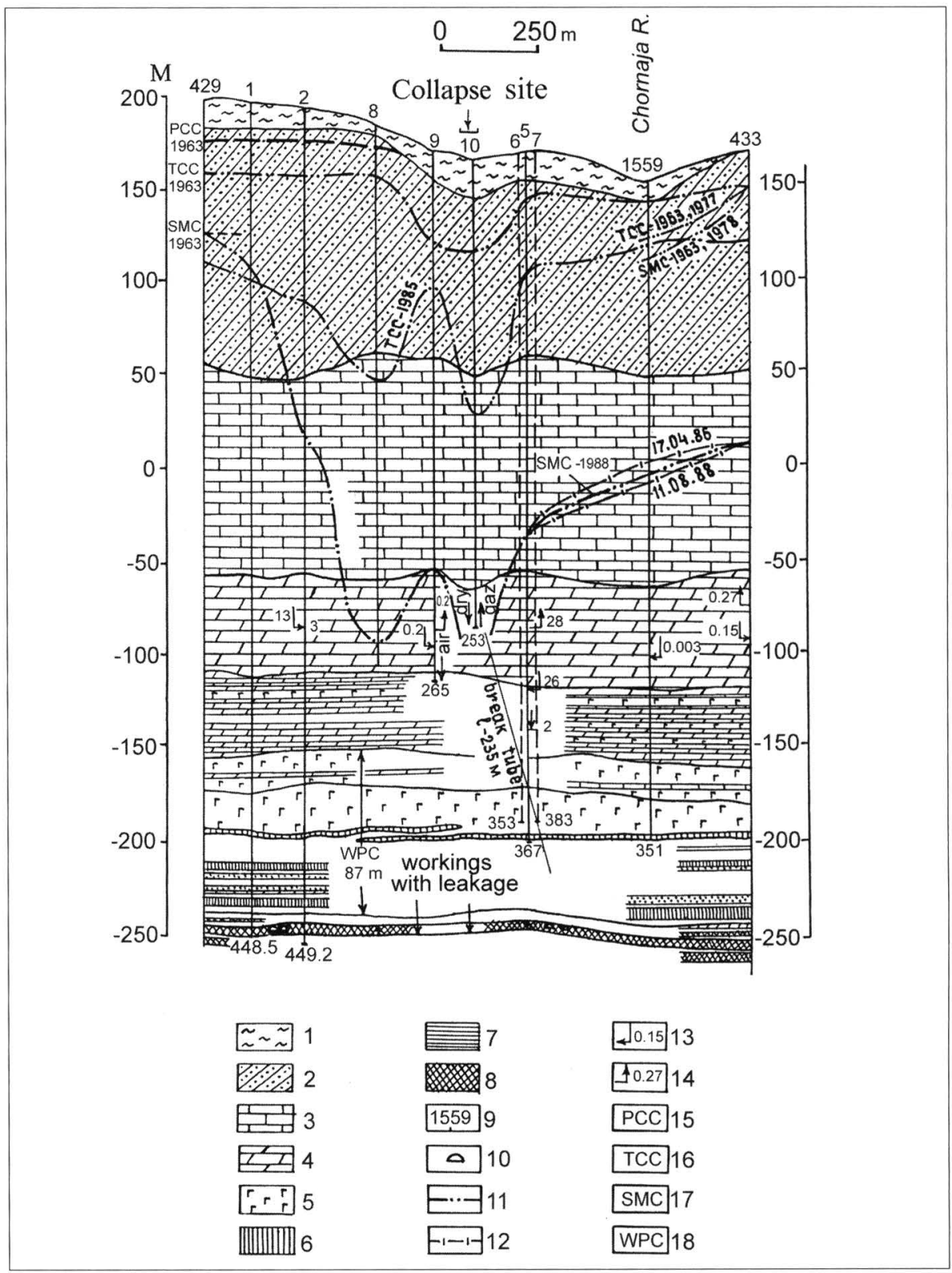

Fig.9 - Hydrodynamic situation in the area of mine flooding and subsequent collapse in May June 1986. 1 = Quaternary sediments, 2 = variegated complex, $3=$ terrigenous-carbonate complex, $4=$ salt-marl sequence, $5=$ rock salt, $6=$ carnallite beds, $7=$ clay, $8=$ sylvinite beds, $9=$ boreholes, $10=$ mines, $11=$ piezometric levels of the freshwater aquifers at the time of borehole drilling, $12=$ level of the brine aquifer, $13=$ water absorption by beds in $L / s, 14=$ water yield in $L$ s. Indexes of aquifers in: $15=$ variegated complex, $16=$ terrigenous-carbonate complex, $17=$ salt-marl sequence, $18=$ waterproof complex. 


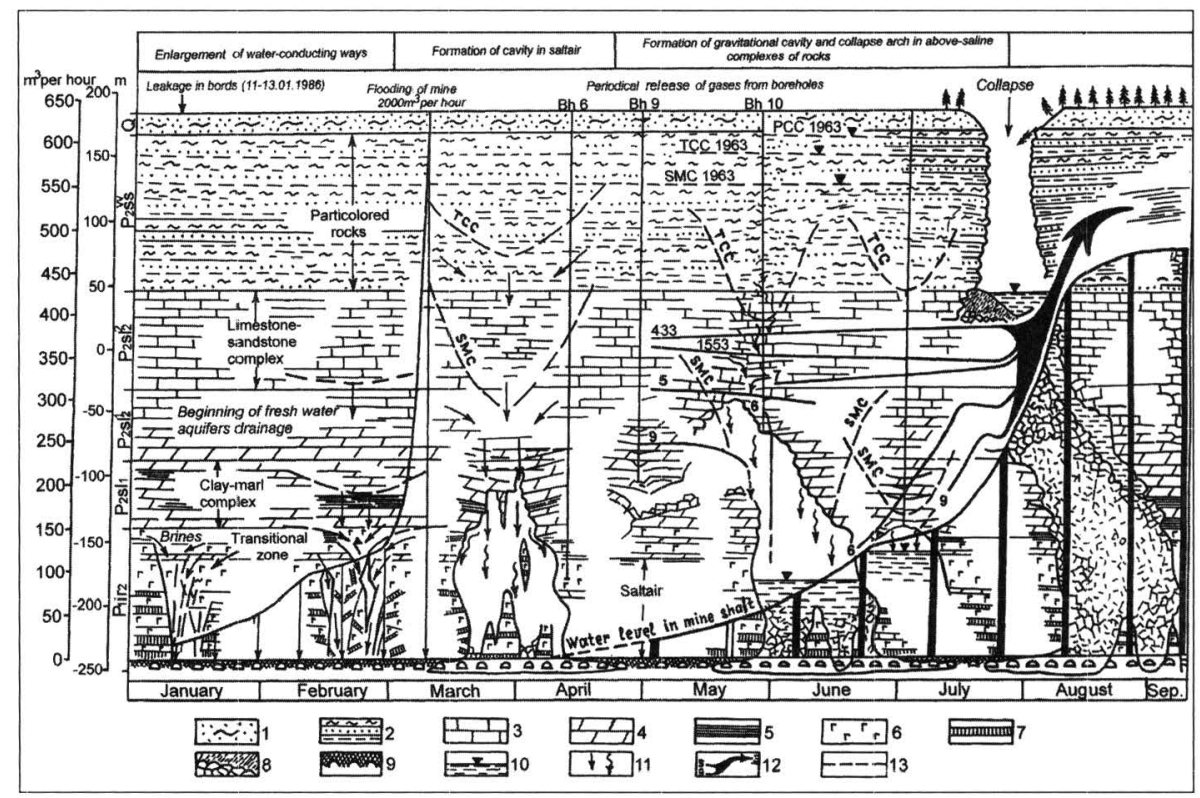

Fig. 10 - Development of conditions and processes in the collapse area in January-August 1986. $1=$ loams and sands, $2=$ argillites, aleurolites and sandstones, $3=$ limestones, $4=$ marls, $5=$ clay, $6=$ rock salt, $7=$ carnallite, $8=$ breakdown deposits, $9=$ sylvinite and mines, $10=$ water level in the cavity, 11 = flow directions, $12=$ water levels in boreholes, and their numbers, $13=$ piezometric surfaces of aquifers as for particular years

determine the average daily water inflow. This would be about $375,000 \mathrm{~m}^{3}$. In reality, the inflow rate was rising throughout. If we assume that the inflow increased uniformly from when the observations ceased (March 9) till mid April, we will obtain the rise from several thousand cubic metres per day (as for March 8-9) to about $750,000 \mathrm{~m}^{3} /$ day (April 20). However, it seems to be more realistic that increase of water inflow was even more dramatic until a certain moment, and then it slowed down to a degree.

Using the volume of the inundated mine one can easily calculate the quantity of dissolved salts and hence estimate the approximate volume of the cavity that had formed in the salt sequence (including the level of the mine). Taking $365 \mathrm{~g} / \mathrm{dm}^{3}$ as an equilibrium concentration (the average between solubilities of halite and sylvinite under $10^{\circ} \mathrm{C}$ ) one can find that during 40 days $5,475,000$ tons of salt had been dissolved, which approximately corresponds to 2.6 million $\mathrm{m}^{3}$ of cave volume (assuming salt density of $\left.2.1 \mathrm{t} / \mathrm{m}^{3}\right)$. At least half of this volume $\left(1.3\right.$ million $\left.\mathrm{m}^{3}\right)$ was dissolved at the mine level. However, because saturation was approached quickly, and because numerous rooms in the mine had large total contact surfaces, most of the dissolution occurred in the damage area.

Thus, by the final third of April the mine was completely flooded and a cavity of about 1.0 to 1.3 million $\mathrm{m}^{3}$ in volume had been formed in the salt sequence above the mine. 


\section{The formation of the collapse}

\subsection{Filling of the cavity by water}

After the mine was flooded, groundwaters began to fill the karstic cavity formed above the mine. We can speculate about these processes from Fig.10. Because the flooded mine, the cavity and the mine shafts are connected hydrodynamically, the water level in the mine shafts corresponds to the level in the cavity. The behaviour of the levels in the shafts shows that filling of the cavity was rather slow. It began in the final third of April, and by the beginning of July the level had reached the first halite bed (the upper limit of the dissolution cavity). Such slow (about 80 days) filling of the cavity, with a volume of about 1.0 - to 1.3 million $\mathrm{m}^{3}$, can be contrasted with the period of the mine flooding, which was half as long for a volume that was an order of magnitude larger. This can be explained by two causes: by further growth of the cavity volume and, more importantly, by a decrease of the inflow. Therefore, during May water inflow decreased considerably, becoming quite small by the beginning of June. Drilling results support this. Borehole No.10, drilled at the end of May, indicated that the lower part of the overburden had been entirely drained (Figs 9 and 10).

Thus, during the period of May (when the drainage of aquifers had ceased) through to the beginning of June the volume of the karst cavity remained almost the same as when it formed in the preceding period. It was revealed later that, above the water level, the dissolution cavity had been filled by a mixture of combustible gases, mainly methane, which accumulated during dissolution of salts.

\subsection{The formation and stoping of the breakout dome}

After the dissolution cavity had been formed, the main processes of its further development were gravitational failure of the roof and upward stoping of the cavity. There was a $300 \mathrm{~m}$-thick overburden separating the dissolution cavity from the surface.

Breakdown material had been gradually filling the original cavity in the salts. In the second half of May the stoping roof had been intercepted by the drilled borehole No.10 at a level of $100 \mathrm{~m}$ above the upper salt bed (Fig.9). This means that even at the beginning of May the cavity had entered the gravitational stage of its development. By the end of June the roof had migrated to a level of $150 \mathrm{~m}$ above the salt.

Starting from the beginning of May, when the cavity was connected to the surface by boreholes, it began to de-gas. Observations on the boreholes' gas regime showed that the gas exchange had an intermittent (inward-outward) character. Periodic release of gases from boreholes continued until the collapse at the end of July. This indicates that the formation of gases continued and suggests continuing dissolution of salts. However, during May and June gravitational processes predominated in the cavity that had formed dissolutionally during April and May. Therefore, active dissolution took place at the salt level in another place, which connected directly with the main gravitational cavity. This is supported by borehole No.9, drilled at the end of April, which intercepted a cavity in a different place, some $150 \mathrm{~m}$ away from boreholes No.10 and No.6, which intercepted the main cavity (Fig.11). The roof of the second cavity was at some 50 to $70 \mathrm{~m}$ above the salt top and therefore this cavity was 


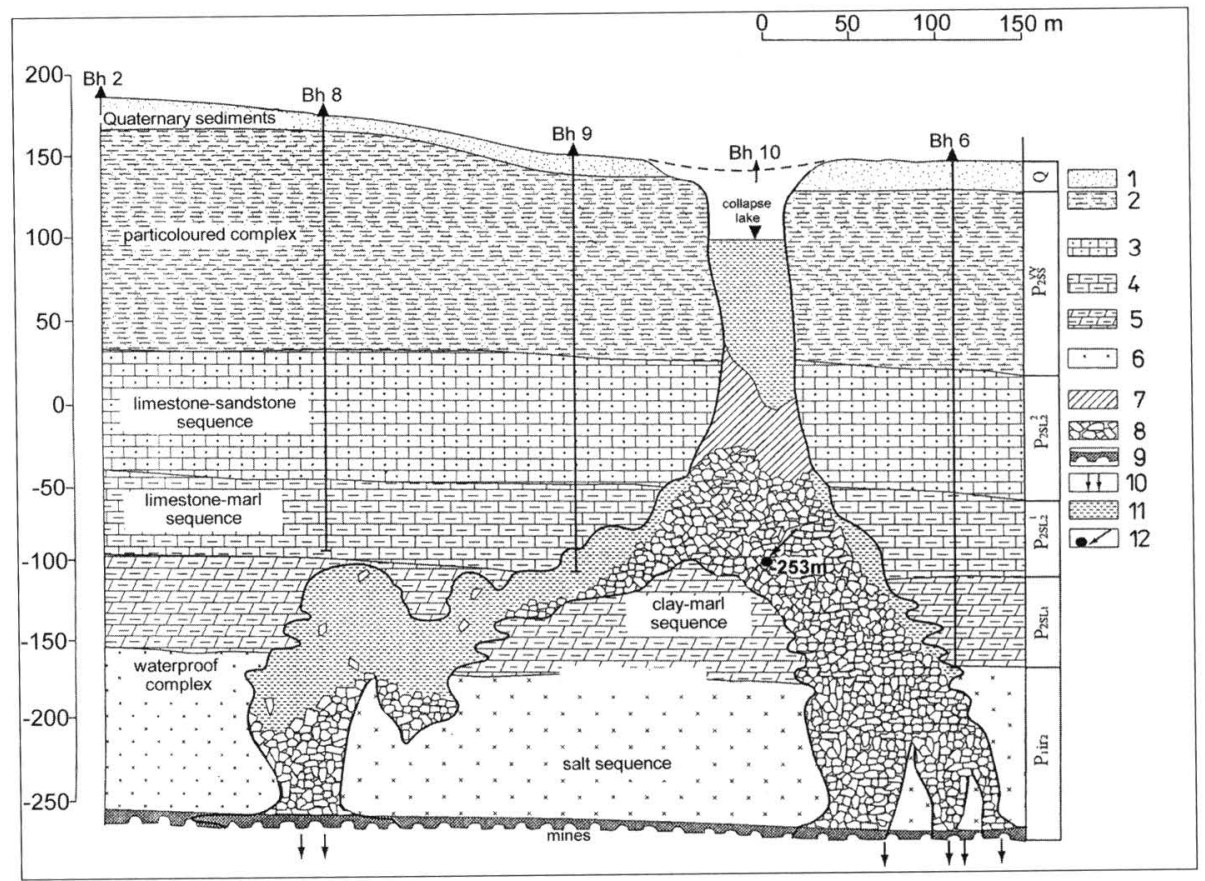

Fig. 11 -General view of the system of dissolutional-gravitational cavities in the collapse area as for the time of the collapse formation. $1=$ loams and sands, $2=$ argillites, aleurolites and sandstones, $3=$ limestones and sandstones, $4=$ clay and marls, $6=$ salt sequence, $7=$ loose mater al of Quaternary sediments, $8=$ breakdown material, $9=$ mines, $10=$ points of brine inflow to the mines (January 11-13), 11 = water, 12 = level of the drilling tool drop while drilling borehole $N^{\circ} 10$ (before the collapse).

already at the gravitational stage. Most likely this was a branch of a single cavity connecting the main gravitational section with another dissolutional cavity in the salt (Fig.11). This is supported by the fact that there was no inflow to the mine at the location of borehole No.9, but an inflow was recorded near borehole No.8, where the neighbouring karstic cavity should be present. The presence of a cavity in that place is also indicated by the presence of a drawdown cone in the brine aquifer revealed by borehole No.8. It was the development of the second dissolution cavity that caused continued periodic gas release from the boreholes.

By the beginning of May there were two cavities present in the area of the subsequent collapse. They had merged by approximately the end of April - beginning of May. The merging of these cavities caused "the effect of the common roof", that is, the common roof was disequilibrated as compared to the roofs of the separate cavities that appeared to be in a more stable state. Besides this effect, the presence of the weakened fold/rupture zone had played a substantial role in the upward stoping of the breakout dome towards the surface.

By the middle of July the roof of the main cavity, stoping along the fold/rupture zone, had reached the bottom of the variegated complex (150 to $160 \mathrm{~m}$ below the surface), and the slowly recovering piezometric level reached absolute elevations of 120 to $130 \mathrm{~m}$ (Fig.10). From this point the intensity of the failure increased dramatically 
due to the clastic and densely stratified nature of the sequence. This statement is supported by evidence of an abrupt raise of groundwater levels in mine shafts and boreholes, which is possible in this situation only due to the fast filling of the cavity by breakdown material that displaced the water. Breakdown of the variegated complex rocks and the roof stoping was particularly intense during the last 10 to 13 days before the collapse. This is illustrated by the fact that during this period the cavity had migrated through the whole thickness of the complex, that is 100 to $120 \mathrm{~m}$. During the last day before the collapse (between 18:30 and midnight, when the collapse occurred) workers in a borehole No.11 facility building clearly felt periodic underground shocks and heard a hum. It is apparent that the shocks were caused by failure of large blocks in the cavity.

\subsection{The collapse}

The collapse occurred at midnight of July 25-26. In contrast to the breakdown process in the variegated complex, the collapse of the $20 \mathrm{~m}$-thick Quaternary "bridge" was instantaneous. The size of the collapse at the ground surface was $40 \times 80 \mathrm{~m}$. Collapsing was accompanied by an explosion with flashes of light. The shock wave was powerful enough to activate an alarm on windows of the mine office located some $1.5 \mathrm{~km}$ distant from the collapse (Fig.12a). The explosion had ejected sandstone and aleurolite clasts from a depth of 25 to $120 \mathrm{~m}$. A $20 \times 15 \times 5 \mathrm{~cm}$ piece of a dark-grey limestone that occurs at a depth of 129 to $130 \mathrm{~m}$, was found at a distance of some $220 \mathrm{~m}$ east

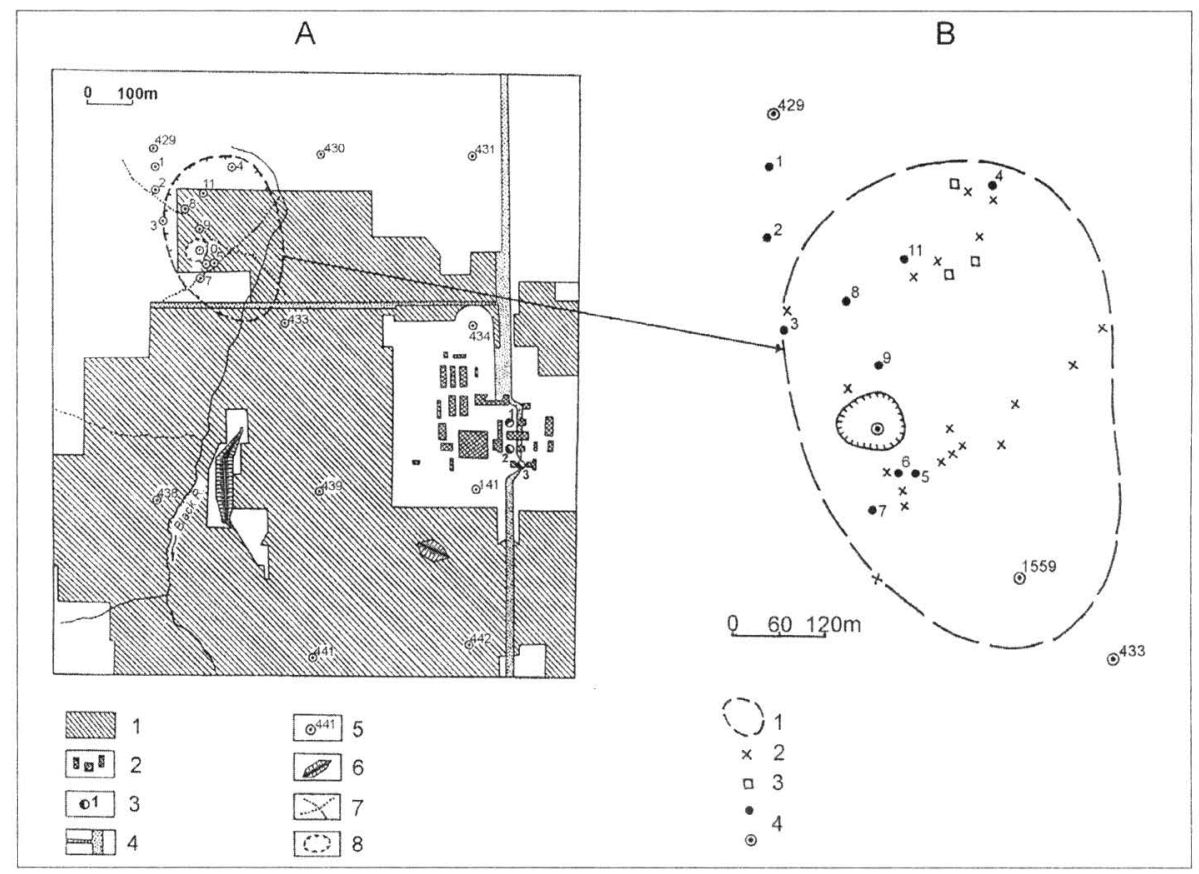

Fig. 12 - The Bereznikovsky No3 mine, the part of the mining field and the location of the collapse. A: 1 = mines, 2 = surface facilities, $3=$ mine shafts and their numbers, $4=$ airways, $5=$ boreholes and their numbers, $6=$ embankment, $7=$ profiles of ground settling measurements, $8=$ collapse contour. $B-$ Distribution of clasts ejected by the explosion: $1=$ area of scatter, $2=$ small clasts, 3 = large clasts, $4=$ special boreholes 
of the collapse. The radius of clasts scatter was several hundred metres (Fig.12b). When striking the ground clasts created craters up to $2 \mathrm{~m}$ in diameter and $1 \mathrm{~m}$ in depth.

The explosion and light effects that accompanied the eventual collapse led some experts to speculations that the collapse was caused by the explosion. They offered the following picture:

- A large cavity was formed due to dissolution, then filled by combustible gases.

- The "gas cavity" migrated upward due to gravitational stoping.

- The explosion occurred when the cavity reached the bottom of the variegated complex, due to enormous gas pressure.

- The explosion had formed the collapse, a kind of a diatreme (Fig.13).

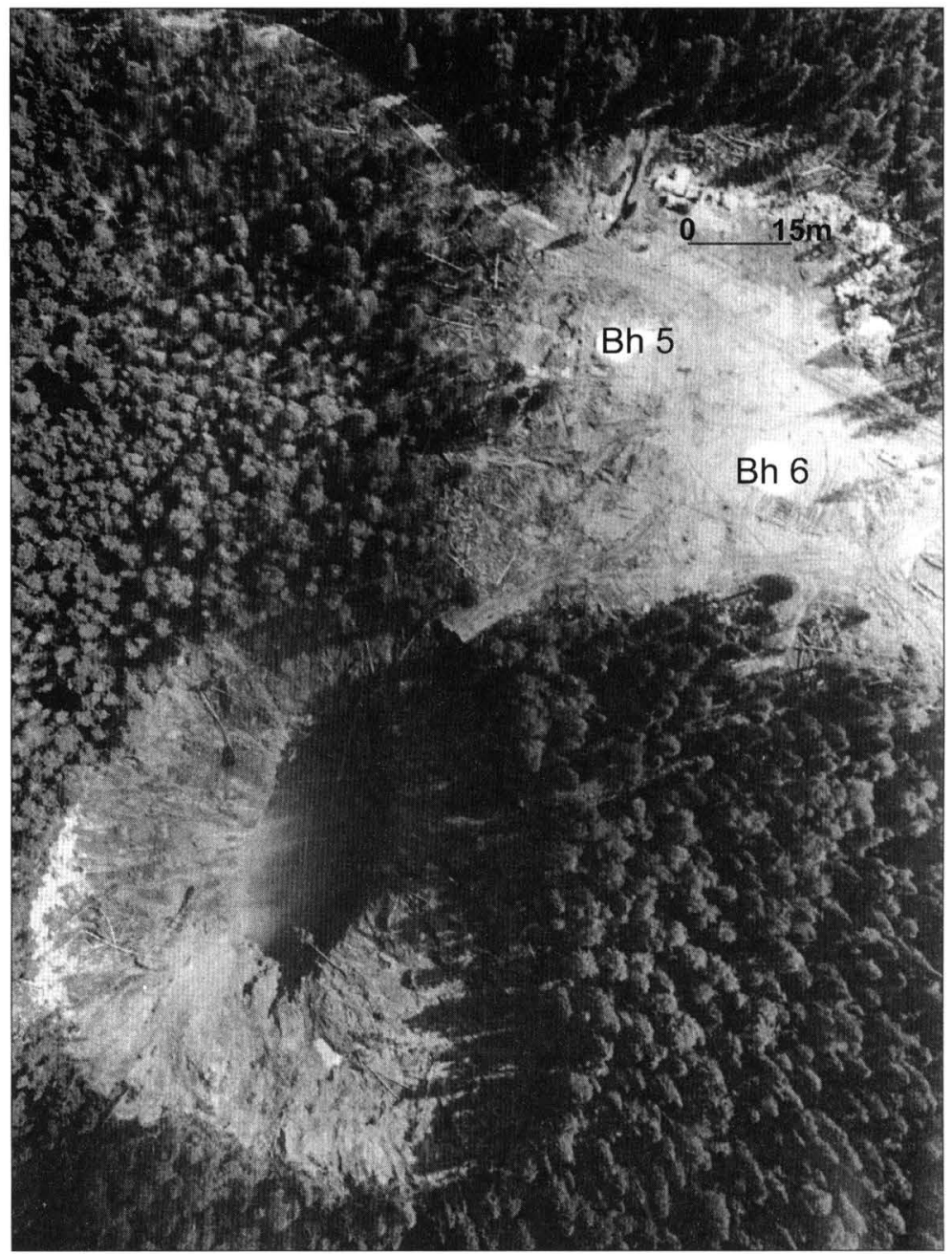

Fig.13 - View of the collapse from a helicopter, as on July 31, 1986. 
The analysis of available data negates this eruptive hypothesis. Firstly, the pressure of gas in the gravitational cavity could not reach anomalous values, as the cavity had aerodynamic connection to the surface via boreholes. In addition, periodic inward suction of air was recorded in boreholes. Moreover, pressure could be released through fissured media and due to dissolution of gases in the water.

Secondly, explosions are effects that commonly accompany collapses, particularly in cases where a breakdown cavity was disconnected from original cavities located at the level of origin (cave systems or mines) by breakdown material. The mass of falling rocks acts as a piston that compresses the air in a closed volume. The compressed air causes a growing counteraction, and at some moment it "shoots" up. Even formation of small collapses commonly causes a loud noise resembling a gunshot (see the paper by Klimchouk and Andrejchuk in this volume).

In the case under study the cavity had been separated from the lower levels by breakdown material (Fig.14). Collapsing of large masses of rocks caused strong compression of air in the cavity. This alone was sufficient for ejection of a large dust column and production of a loud noise. Moreover, the cavity was filled by combustible gases. Their ignition, probably caused by sparking from the falling drill string of borehole No.10, had added the lighting effects to the explosion and amplified the noise effect. Conditions for gas explosion were created by the piston effect. Ignition of compressed gases amplified the pneumatic explosion and added the chemical component. The resulting power of the explosion had proven to be sufficient for ejec-

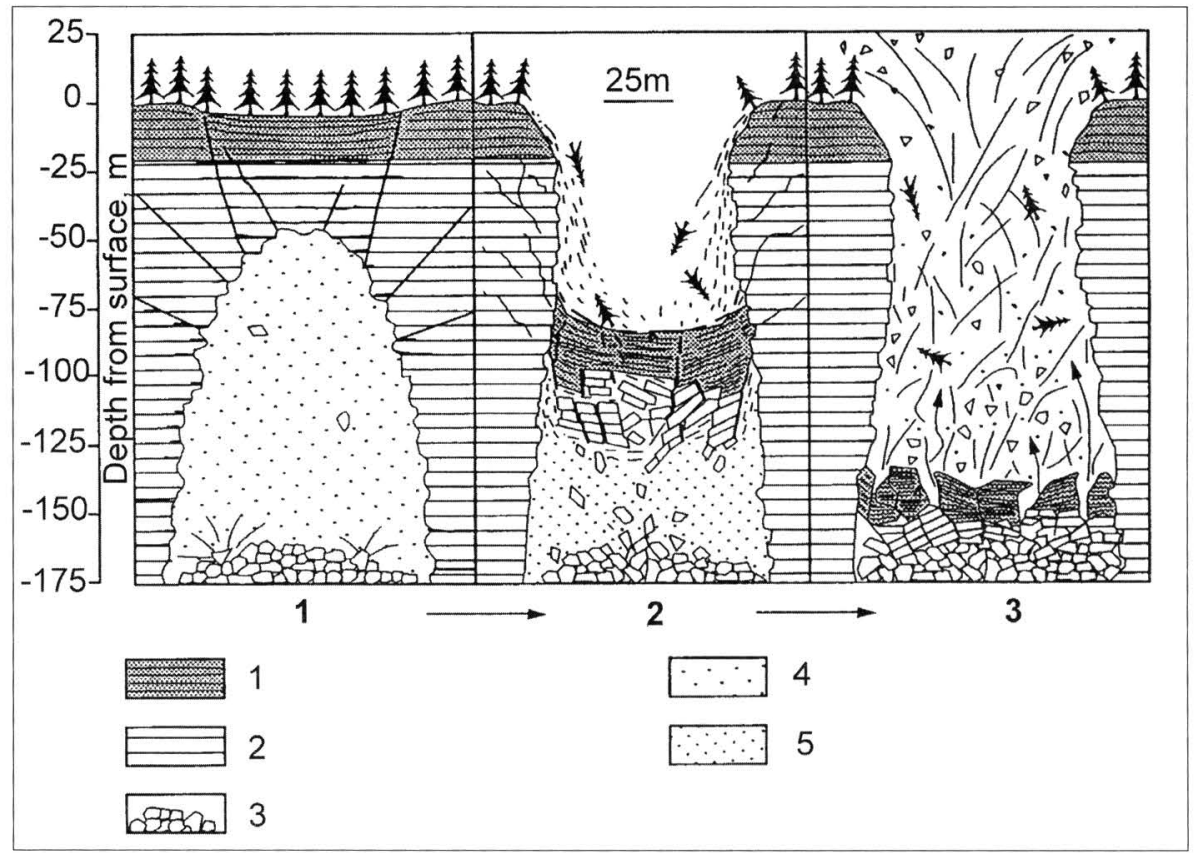

Fig. $14-$ A sketch illustrating failure of isolated cavity and explosion ejection of rock clasts: $1=$ fluvioglacial sequence, 2 = variegated complex, 3 = breakdown deposits, 4 = gas-air mixture, 5 = compressed gas-air mixture 


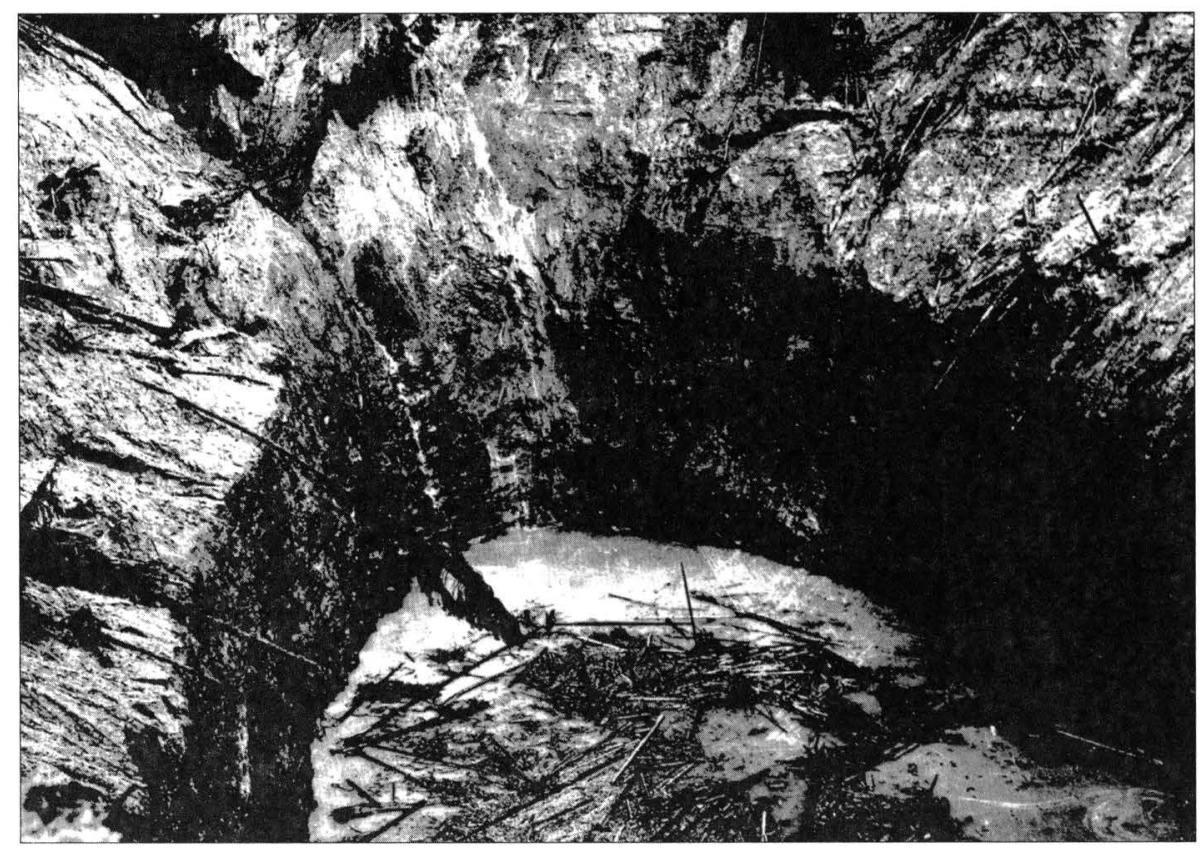

Fig.15 - View to the northwestern side of the collapse (June 1987).

tion of not only aleuritic and sandy particles but also of relatively large clasts. The action of the explosion was directed upwards, which is suggested by the fact that trees surrounding the collapse were neither thrown down nor burned. Therefore, the explosion was not the cause of the collapse but its consequence.

After the collapse occurred, a deep asymmetrical doline appeared, with steep slopes at the level of the fluvioglacial sequence and vertical walls at the level of the variegated complex (Fig.15). Its initial ground plan dimensions were about $80 \mathrm{~m}$ along the long axis and $40 \mathrm{~m}$ along the short axis (Fig.16). The long axis was oriented northwest-southeast, which coincided with the orientation of the fold and an associated ravine. For short period the doline assumed a cone shape in the upper part, at the level of the Quaternary sediments.

It was difficult to determine the depth of the collapse doline immediately after formation. The bottom could not be observed from a helicopter because of grey fog that filled the doline (Fig.13). Most likely, it was a mixture of water vapour, gases and dust. On August 8, half a month after collapsing, water appeared in the lower part, some $100 \mathrm{~m}$ below the ground surface. It can be seen on Fig. 10 that during the first ten days after the event the groundwater table in shafts and boreholes had been rising even more steeply than before. This was due to a continued massive fall-in of rocks into the doline. By the end of August the groundwater level had stabilised at a depth of 60 to $70 \mathrm{~m}$ below the surface, and it continued to rise gradually after that. The water came from the variegated complex, Quaternary deposits and surface runoff. By the end of the 1980s the water level stabilised again at the depth of 36 to $40 \mathrm{~m}$ below the surface. After that the doline began to fill up due to landslides and 


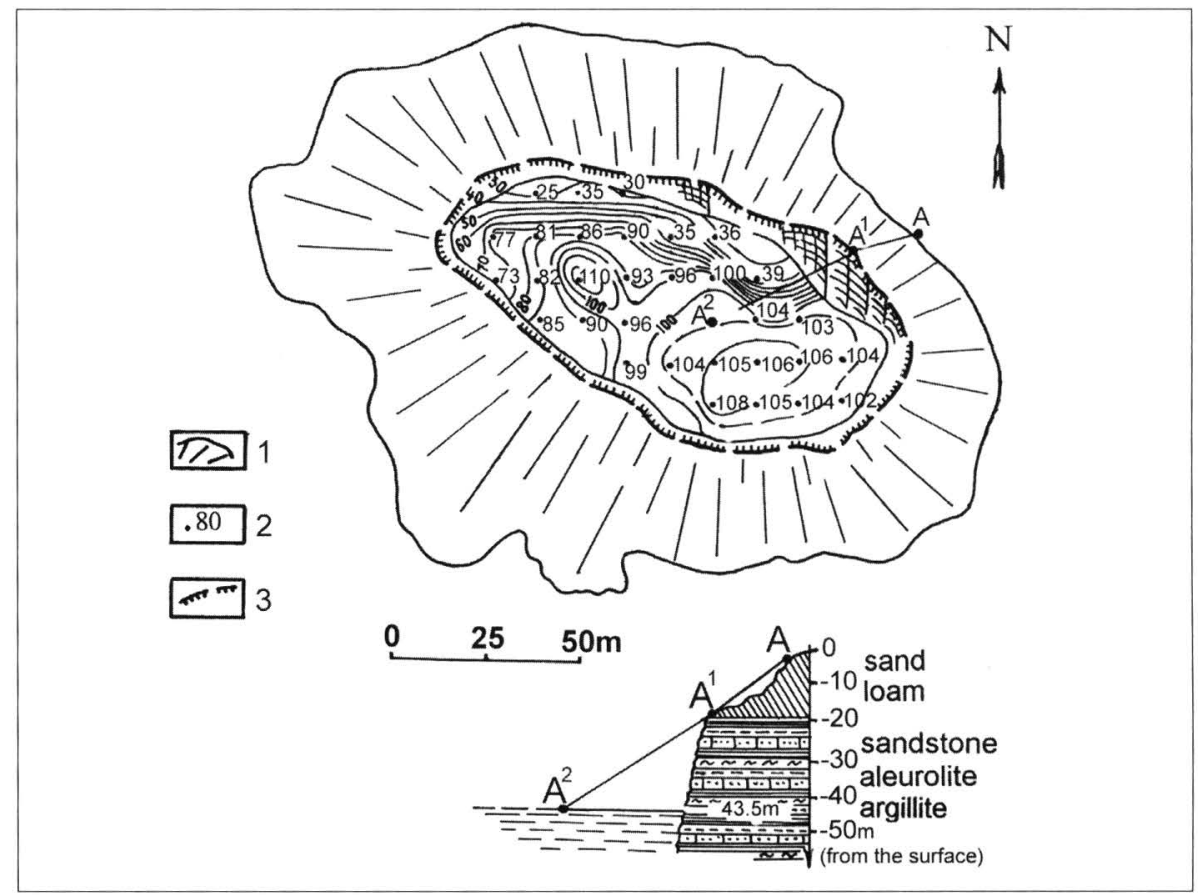

Fig.16 - Plan of the collapse doline as for beginning of 1988: 1 = gentle slopes (in the fluvioglacial sediments), 2 = depth of the lake at the bottom (from the water surface to the bottom), $3=$ edge of the vertical walls (in the variegated complex

erosion. While the initial depth (from the surface to the bottom of the lake) was about $150 \mathrm{~m}$ as a minimum, by $1992-1993$ it decreased to 80 to $100 \mathrm{~m}$. During this period the width of the upper part of the doline increased to 150 to $200 \mathrm{~m}$.

The Bereznikovsky Collapse is a spectacular example of anthropogenicallyinduced catastrophic collapse, caused by a mechanism that is characterised by all the signs of karst breakdowns.

\section{REFERENCES}

ANDREJCHUK V.N. 1989. Fissuring of the Ufimsky Formation (variegated sequence) in the walls of the Bereznikovsky Collapse. 13-14. In: Problemy isuchenija vodozashchitnoj tolshchi Verhnekamskogo mestorozhdenija kalijnykh solej. Berezniki. (in russian).

ANDREJCHUK V.N. 1996. The Bereznikovsky Collapse. Geoekologija 1: 17-34. (in russian).

ANDREJCHUK V.N. and LUKIN V.S. 1988. The Great Bereznikovsky Collapse. 33-34. In: Problemy isuchenija vodozashchitnoj tolshchi Verhnekamskogo mestorozhdenija kalijnykh solej. Berezniki. (in russian).

KOPNIN V.I. 1995. Verkhnekamsky deposit of potassium, potassium-magnesium and rock salts and natural brines. Gorny Zhurnal 6: 10-43. (in russian).

KOTEL'NIKOV A.N. and MINKEVICH I.I. 1990. Hydrogeological conditions of the formation of a collapse on the field of BKRU-3 mine. 49-50. In: Katastrofy i avarii na zakarsto 
vannykh territorijakh. Perm. (in russian)

FILIPPOV C.A. and KOROCHKINA S.F. 1990. Evidences of disjunctive tectonics in the productive sequence of the Verkhnekamsky potash deposit. Geotektonika 1: 64-67. (in russian)

YARZHEMSKIJ Ya.Ya. and TRETJAKOV Ju.A. 1989. Secondary transformations of salt rocks of the Verkhnekamsky deposit. Lithologija i poleznyje iskopaemyje 2: 85-91. (in russian). 